\title{
UPAYA PENINGKATAN PENGETAHUAN REMAJA DALAM PENDEWASAAN USIA PERKAWINAN DIMASA PANDEMI COVID-19
}

\author{
Linda Meliati ${ }^{1}$, Lina Sundayani ${ }^{11}$ \\ 1) Jurusan Kebidanan, Poltekkes Kemenkes Mataram, Mataram, NTB, Indonesia \\ Corresponding author : Linda Meliati \\ E-mail : meliatilinda@gmail.com
}

Diterima 28 Novemebr 2021, Direvisi 11 Desember 2021, Disetujui 11 Desember 2021

\begin{abstract}
ABSTRAK
Faktor penyebab tingginya angka pernikahan usia dini adalah rendahya pengetahuan dan pemahaman remaja, dampak pernikahan usia dini dan kesehatan reproduksi remaja. Pemahaman masyarakat tentang dampak yang akan ditimbulkan, faktor kemiskinan, faktor pendidikan, kultur sosial dan budaya serta adanya pengaruh media dan lingkungan menyebabkan terjadinya perubahan sikap dan perilaku remaja. Tujuan pengabdian masyarakat ini adalah memberikan informasi dan edukasi kepada remaja tentang Pendewasaan Usia Perkawinan (PUP) dalam merencanakan keluarga, aspek yang berhubungan dengan kehidupan berkeluarga, kesiapan fisik, mental, emosional, pendidikan, sosial, ekonomi, menentukan jumlah dan jarak kelahiran di masa Covid-19. Kegiatan ini dilaksanakan di Lingkungan Tegal Sejahtera Kelurahan Selagalas Kecamatan Sandubaya. Metode kegiatan dengan metode ceramah dan memberikan pendidikan kesehatan. Penilaian dari pengabdian masyarakat ini dari hasil jawaban remaja dalam mengisi kuesioner pretest dan postest. Metode analisis yang digunakan dengan analisis deskriptif. Penilaian dari kuesioner pengetahuan dan sikap remaja adalah sebagian besar remaja berpengetahuan baik dan mempunyai sikap positif, namun ada 1 orang remaja yang mempunyai niat untuk melakukan pernikahan dini, ini disebabkan karena belum pernah mendapatkan informasi tentang Pendewasaan Usia Perkawinan. Setelah diberikan penyuluhan tentang Pendewasaan Usia Perkawinan, ada peningkatan pengetahuan dan sikap pada remaja tersebut. Kegiatan ini berhasil meningkatkan pengetahuan remaja serta mempunyai sikap positif dalam Pendewasaan Usia Perkawinan.
\end{abstract}

Kata kunci : covid-19; pengetahuan; perkawinan; remaja

\begin{abstract}
Factors causing the high rate of early marriage are the low knowledge and understanding of adolescents, the impact of early marriage and adolescent reproductive health. Public understanding of the impact that will be caused, poverty factors, educational factors, social and cultural culture as well as the influence of the media and the environment cause changes in adolescent attitudes and behavior. The purpose of this community service is to provide information and education to teenagers about Maturation of Marriage Age (PUP) in family planning, aspects related to family life, physical, mental, emotional, educational, social, economic readiness, determining the number and spacing of births during the Covid period. -19. This activity was carried out in the Tegal Sejahtera Environment, Selagalas Village, Sandubaya District. The activity method is the lecture method and provides health education. The assessment of this community service is based on the results of the adolescents' answers in filling out the pretest and posttest questionnaires. The analytical method used is descriptive analysis. The assessment of the adolescent knowledge and attitude questionnaire is that most of the adolescents have good knowledge and have a positive attitude, but there is one teenager who has the intention to have an early marriage, this is because they have never received information about Marriage Age Maturity. After being given counseling about the Maturation of Marriage Age, there was an increase in the knowledge and attitudes of these teenagers. This activity succeeded in increasing the knowledge of adolescents and having a positive attitude in Maturing Marriage Age.
\end{abstract}

Keywords: covid-19; knowledge; marriage; teens

\section{PENDAHULUAN}

Di Provinsi NTB isu pernikahan usia dini cukup tinggi. Data BPS menunjukan persentase perkawinan pertama perempuan umur 10-19 tahun pada tahun 2016 sebesar 51,19\%, dengan rata-rata usia kawin pertama perempuan masih dibawah target (15,20 tahun) dari target 20,50 tahun. Faktor penyebab tingginya angka pernikahan usia dini antara lain adalah rendahya pengetahuan dan 
pemahaman remaja, tentang dampak pernikahan usia dini dan kesehatan reproduksi remaja. Pemahaman masyarakat tentang dampak yang akan ditimbulkan, faktor kemiskinan, faktor pendidikan, kultur sosial dan budaya serta adanya pengaruh media dan lingkungan menyebabkan terjadinya perubahan sikap dan perilaku remaja. Terjadinya perkawinan usia muda di NTB ini mempunyai dampak tidak baik kepada mereka yang telah melangsungkan pernikahan juga berdampak pada anak-anak yang dilahirkannya serta masing-masing keluarganya.

Berdasarkan data kasus pernikahan dini usia 17-19 tahun di Kota Mataram terjadi peningkatan yaitu pada tahun 2017 sebesar 229 dan tahun 2018 sebesar 283 kasus (Ariany, 2019). Data kasus pernikahan dini pada masa Pandemi Covid-19 di NTB jumlah pelajar jenjang SMA sederajat yang menikah sebesar 148 kasus. Pada bulan Januari sampai 8 September 2020 dispensasi Nikah dipengadilan Agama sebesar 522 kasus. Kasus kehamilan pada anak di kabupaten Lombok Utara sebesar 408 kasus dan data perceraian sebesar 5560 kasus (Ariany, 2020).

Pernikahan di usia remaja dapat berdampak pada segi fisik maupun biologis. Kehamilan remaja akan lebih beresiko terjadi anemia dan perdarahan yang akan menyumbang angka kematian ibu dan bayi. Dalam segi pendidikan remaja yang hamil akan kehilangan kesempatan melanjutkan pendidikan yang lebih tinggi. Setelah menikah pada usia muda, seorang wanita akan cenderung kurang memperhatikan pendidikannya, apabila ketika menikah langsung memperoleh keturunan, ia akan disibukkan mengurus anak dan keluarganya, sehingga hal ini dapat menghambatnya untuk melanjutkan pendidikannya. Hal tersebut dapat diminimalisir dengan dukungan dari keluarga. Selain itu peluang untuk mendapat kesempatan kerja akan semakin sempit (Mubasyaroh, 2016). $\begin{array}{ccc}\text { Dampak sosial lainnya adalah } \\ \text { berkurangnya } & \text { sosialisasi } & \text { dengan }\end{array}$ lingkungannya. Bagi pasangan pernikahan dini, hal ini dapat berpengaruh dalam berhubungan dengan teman sebaya. Mereka akan sulit untuk beradaptasi dan canggung untuk bergaul kembali dengan teman sebayanya. Mereka berada pada kondisi yang tidak menentu dalam status sosial, karena ketika bergaul dengan orang tua, relitasnya mereka masih remaja, begitu juga sebaliknya, mau main dengan teman sebayanya yang remaja, kenyataannya mereka sudah berstatus sebagai suami maupun istri. Maka bereka harus mampu beradaptasi dengan lingkungan sosialnya dengan baik (Mubasyaroh, 2016).
Salah satu program pembangunan yang berkaitan dengan kependudukan adalah Program Keluarga Berencana yang bertujuan mengendalikan jumlah penduduk diantaranya melalui program Pendewasaan Usia Perkawinan (PUP). Pendewasaan Usia Perkawinan bertujuan untuk memberikan pengertian dan kesadaran kepada remaja agar di dalam merencanakan keluarga, mereka dapat mempertimbangkan berbagai aspek berkaitan dengan kehidupan berkeluarga, ditinjau dari aspek kesehatan, ekonomi, psikologi dan agama. Tujuan PUP seperti ini berimplikasi pada perlunya peningkatan usia perkawinan yang lebih dewasa sehingga berdampak pada penurunan Total Fertility Rate (TFR) (BKKBN, 2010),(BKKBN, 2012).

Berdasarkan hasil penelitian didapatkan bahwa ada hubungan antara pengetahuan terhadap sikap remaja tentang pendewasaan usia perkawinan (Hartati, Verawati, \& Ernawati, 2019) dan selain itu juga adanya peningkatan pengetahuan anggota karang taruna sebelum kegiatan dan sesudah kegiatan dengan pemberian pendidikan kesehatan (Putri \& Rosida, 2019).

Salah satu upaya pencegahan pernikahan usia dini yang perlu dilakukan untuk pendewasaan usia perkawinan pada remaja dimasa Covid-19 dengan memberikan penyuluhan kesehatan di Lingkungan Tegal Sejahtera Kelurahan Selagalas Kecamatan Sandubaya Kota Mataram. Tujuan pengabdian masyarakat ini adalah memberikan informasi dan edukasi kepada remaja tentang Pendewasaan Usia Perkawinan (PUP) dalam merencanakan keluarga, aspek yang berhubungan dengan kehidupan berkeluarga, kesiapan fisik, mental, emosional, pendidikan, sosial, ekonomi, menentukan jumlah dan jarak kelahiran di masa Covid-19.

\section{METODE}

Kegiatan pengabdian masyarakat ini diikuti oleh remaja Karang Taruna sebanyak 7 orang di Lingkungan Tegal Sejahtera Kelurahan Selagalas Kecamatan Sandubaya, pada hari Selasa, tanggal 22 September 2020.

Metode pelaksanaan dalam pengabdian masyarakat ini adalah terdiri dari :

\section{A. Tahap Pelaksanaan}

Metode yang digunakan untuk menyelesaikan permasalahan yaitu dengan pemberian pendidikan kesehatan tentang KIE program pendewasaan usia perkawinan. Solusi yang disepakati bersama mitra adalah memberikan penyuluhan pada remaja mengenai program Pendewasaan Usia Perkawinan (PUP). Kehadiran para remaja di tengah masyarakat akan membantu remaja 
mengenal program Pendewasaan Usia Perkawinan (PUP) di masa Pandemi Covid-19.

Adapun tahap pelaksanaan kegiatan sebagai berikut:

1) TAHAP 1: Assesment

Pendataan terkait pengetahuan dan sikap pendewasaan usia perkawinan pada remaja (pretest). Mitra berperan dalam mengumpulkan remaja dan mengisi kuesioner pretest.

2) TAHAP 2 : Planning and Development

Perencanaan dan persiapan terkait program PUP. Menyusun propoposal, dan media penyuluhan serta menyusun jadwal pelaksanaan program. Mitra berperan turut dalam merencanakan jadwal program. Hasil yang disepakati dengan mitra yaitu pelaksanaan kegiatan pada tanggal 22 September 2020, dimulai pada pukul 09.00 WITA sampai dengan selesai di Lingkungan Tegal Sejahtera Kelurahan Selagalas Kecamatan Sandubaya

3) TAHAP 3 : Implementation

Pada tahap ini direncanakan pelaksanaan kegiatan sesuai dengan yang direncanakan sebelumnya yaitu pada tanggal 22 September 2020 di Lingkungan Tegal Sejahtera Kelurahan Selagalas Kecamatan Sandubaya.

\section{B. Strategi Pelaksanaan}

Strategi pelaksanaan dalam kegiatan PKM "Upaya Peningkatan Pengetahuan Remaja Dalam Pendewasaan Usia Perkawinan di Masa Pandemi Covid-19 di Lingkungan Tegal Sejahtera Kelurahan Selagalas Kecamatan Sandubaya Tahun 2020" dilaksanakan dengan strategi sebagai berikut:

Tabel 1. Strategi Pelaksanaan

\begin{tabular}{lll}
\hline \multicolumn{1}{c}{ Input } & \multicolumn{1}{c}{ Proses } & \multicolumn{1}{c}{ Output } \\
\hline - Menjelaskan & - Mengisi & - Remaja \\
tujuan & absensi & memahami \\
kegiatan & kegiatan, & serta \\
- Melakukan & kuesioner & mengetahui \\
evaluasi awal & awal & tentang \\
(pretest) pada & (pretest) & Pendewasaan \\
remaja & dan & Usia \\
dengan & mengikuti & Perkawinan \\
mengisi & paparan & (PUP) \\
kuesioner & materi & - Adanya \\
pertanyaan & - Mengisi & peningkatan \\
- Memberikan & kuesioner & pengetahuan \\
materi tentang & akhir & remaja tentang \\
Pendewasaan & (posttest) & Pendewasaan \\
Usia & & Usia \\
Perkawinan & & Perkawinan \\
(PUP) & & (PUP) \\
- Melakukan & & \\
evaluasi akhir & & \\
(posttest) & & \\
pada remaja & & \\
dengan & & \\
mengisi & & \\
\hline
\end{tabular}

kuesioner

pertanyaan

\section{Tahap Evaluasi}

1. Evaluasi pelaksanaan

Evaluasi saat pelaksanaan selama proses penyuluhan kesehatan meliputi kemampuan remaja dalam menjawab soal.

2. Evaluasi hasil

Evaluasi hasil pengetahuan remaja dilakukan dengan angket tanya jawab dengan mengisi kuesioner yang diberikan

3. Evaluasi luaran

Evaluasi luaran adalah terdapat peningkatan pengetahuan remaja sebelum dan sesudah diberikan penyuluhan. Untuk pengetahuan remaja hasil luaran dapat dilihat dari jawaban remaja dari kuesioner sebelum dan sesudah diberikan.

\section{HASIL DAN PEMBAHASAN}

Kegiatan ini dilaksanakan dengan memberikan edukasi pada remaja tentang Pendewasaan Usia Perkawinan (PUP) pada remaja di Masa Pandemi Covid-19 yang datang di Lingkungan Tegal Sejahtera Kelurahan Selagalas Kecamatan Sandubaya, secara umum kegiatan ini berlangsung lancar dan baik. Petugas PLKB serta remaja Karang Taruna membantu mempersiapkan tempat dan mengkoordinir peserta selama kegiatan penyuluhan berlangsung. Kegiatan penyuluhan PUP (Pendewasaan Usia Perkawinan) ini diselenggarakan pada tanggal 22 September 2020.

Hasil pelaksanaan kegiatan edukasi remaja tentang Pendewasaan Usia Perkawinan yang hadir berdasarkan karakteristik (Tabel 1),

Tabel 2. Karakteristik Remaja Dalam Upaya Pendewasaan Perkawinan

\begin{tabular}{llcc}
\hline No & Karakteristik & $\mathbf{f}$ & $\%$ \\
& & & \\
\hline 1 & Jenis Kelamin & & \\
\hline 2 & Perempuan & 3 & 42,9 \\
\hline & Laki-Laki & 4 & 57,1 \\
\hline 1 & Pendidikan & & \\
\hline 2 & Menengah & 1 & 14,2 \\
\hline
\end{tabular}


Tabel 2 terlihat bahwa peserta dalam pengabdian masyarakat ini dengan karakteristik berdasarkan jenis kelamin terbanyak adalah laki-laki sebanyak 4 orang $(57,1 \%)$ dan berdasarkan pendidikan terbanyak adalah pendidikan tinggi sebanyak 6 orang $(85,8 \%)$. Dari peserta yang hadir dalam pengabdian masyarakat ini terlihat bahwa sebagian besar adalah laki-laki. Pada remaja laki-laki dan perempuan sebaiknya dilakukan pendewasaan usia perkawinan yaitu dimana masa menunda perkawinan dan kehamilan disebabkan karena organ reproduksi masih berkembang baik pada laki-laki maupun pada perempuan. Perempuan berakhir pertumbuhan organ reproduksinya pada usia 20 tahun sedangkan pada laki-laki pertumbuhan organ reproduksinya berakhir pada usia 20 atau 21tahun. Dampak remaja perempuan ataupun laki-laki dengan menikah dalam usia muda menyebabkan keluarga sering tidak harmonis, sering cekcok, terjadi perselingkuhan, KDRT, rentan terhadap perceraian.

Sebelum memulai kegiatan penyuluhan, pelaksana terlebih dahulu memperkenalkan diri kemudian memberikan pertanyaan dengan menggali pengetahuan dasar remaja melalui kegiatan pretest tentang materi Pendewasaan Usia Perkawinan (PUP). Berdasarkan hasil pretest menunjukkan bahwa remaja di Lingkungan Tegal Sejahtera Kelurahan Selagalas Kecamatan Sandubaya sebelum diberikan penyuluhan tentang Pendewasaan Usia Perkawinan (PUP) memiliki tingkat pengetahuan baik sebesar 5 orang remaja $(71,4 \%)$, tingkat pengetahuan cukup sebesar 2 orang remaja $(28,6 \%)$ dan tingkat pengetahuan remaja yang kurang tidak ada.

Sebagian besar tingkat pengetahuan remaja adalah baik tentang Pendewasaan Usia Perkawinan (PUP). Ini dikarenakan remaja tersebut sudah pernah mendapatkan informasi tentang Pendewasaan Usia Perkawinan dan dapat menyehatkan alat reproduksi pada remaja wanita dan laki-laki. Sumber informasi yang diperoleh terbanyak dari tenaga kesehatan sebesar 5 orang $(71,4 \%)$, sisanya sumber informasi diperoleh internet, televisi, buku, koran atau majalah.

Hal-hal yang mempengaruhi remaja berpengetahuan baik ialah remaja mengerti dan memahami tujuan pendewasaan usia perkawinan, faktor penyebab terjadinya usia muda serta tingginya angka kematian ibu dan bayi merupakan resiko kehamilan di usia muda.

$$
\text { Proses penyuluhan tentang }
$$

Pendewasaan Usia Perkawinan (PUP) berjalan lancar. Acara dihadiri oleh 7 orang remaja yang merupakan perwakilan dari Karang Taruna yang berasal dari Lingkungan Tegal Sejahtera
Kelurahan Selagalas Kecamatan Sandubaya. Pada saat penyampaian materi penyuluhan, remaja sangat antusias dan memperhatikan dengan seksama materi yang disampaikan pelaksana bahkan beberapa remaja ada yang aktif bertanya seputar materi yang disampaikan. Adapun suasana kegiatan penyuluhan pada remaja di Lingkungan Tegal Sejahtera Kelurahan Selagalas Kecamatan Sandubaya dalam upaya Pendewasaan Usia Perkawinan (PUP) seperti Gambar 1 dibawah ini

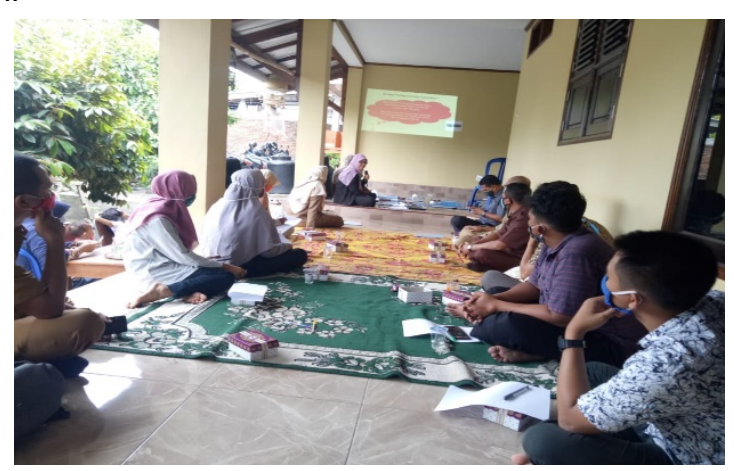

Gambar 1. Suasana Penyuluhan Pada Remaja Dalam Upaya Pendewasaan Usia Perkawinan

Pernikahan di usia remaja dapat berdampak pada segi fisik maupun biologis. Kehamilan remaja akan lebih beresiko terjadi anemia dan perdarahan yang akan menyumbangkan angka kematian ibu dan bayi. Dalam segi pendidikan remaja yang hamil akan kehilangan kesempatan melanjutkan pendidikan yang lebih tinggi. Setelah menikah pada usia muda, seorang wanita akan cenderung kurang memperhatikan pendidikannya, apabila ketika menikah langsung memperoleh keturunan, ia akan disibukkan mengurus anak dan keluarganya, sehingga hal ini dapat menghambatnya untuk melanjutkan pendidikannya. Hal tersebut dapat diminimalisir dengan dukungan dari keluarga. Selain itu peluang untuk mendapat kesempatan kerja akan semakin sempit (Mubasyaroh, 2016).

Menurut (Notoatmodjo, 2010) pengetahuan merupakan hasil tahu yang terjadi setelah orang melakukan penginderaan suatu objek melalui panca indra. Pengetahuan merupakan domain yang penting sehingga terbentuknya tindakan seseorang. Remaja telah diberikan informasi kesehatan melalui penyuluhan, dari kegiatan tersebut remaja mampu menjelaskan tentang Pendewasaan Usia Perkawinan. Metode yang digunakan adalah dengan diskusi serta tanya jawab. Kegiatan pengabdian masyarakat ini menggunakan media video dan power point 
tentang Upaya Pendewasaan Usia Perkawinan yang telah dibuat oleh pelaksana. Peningkatan pengetahuan remaja dilakukan dengan memberikan penyuluhan yang bertujuan untuk memberikan edukasi pada remaja dalam upaya Pendewasaan Usia Perkawinan.

Setelah kegiatan penyuluhan, maka hal selanjutnya yang dilaksanakan adalah melaksanakan evaluasi kepada 7 orang remaja dengan memberikan soal posttest untuk mengukur pemahaman remaja tersebut. Hasil penyuluhan upaya Pendewasaan Usia Perkawinan (posttest) didapatkan bahwa hasil remaja yang berpengetahuan baik meningkat menjadi 6 orang $(85,8 \%)$, untuk pengetahuan cukup mmenjadi 1 orang $(14,2 \%)$. Dari hasil penyuluhan tersebut dapat dilihat terjadi peningkatan pengetahuan remaja sesudah diberikan penyuluhan dalam upaya Pendewasaan Usia Perkawinan, namun ada 1 orang yang belum pernah mendapatkan materi tentang Pendewasaan Usia Perkawinan.

Pencegahan dalam perkawinan usia dini dilakukan dengan memberikan penyuluhan kepada remaja, agar Pendewasaan Usia Perkawinan dimulai dari remaja dalam upaya untuk meningkatkan usia pada perkawinan pertama, sehingga pada saat perkawinan, perempuan mencapai minimal usia 20 tahun dan laki-laki usia 25 tahun. Pendewasaan Usia Perkawinan dan perencanaan keluarga adalah menunda perkawinan dan kehamilan, masa mencegah kehamilan, masa menjarangkan kehamilan, masa mengakhiri kehamilan. Masa menunda kehamilan pada perempuan organ reproduksi masih berkembang dan pertumbuhan organ reproduksi perempuan berakhir tumbuh usia 20 tahun serta laki-laki pertumbuhan organ reproduksi berakhir tumbuh usia 20 atau 21 tahun.

Selain penyuluhan yang diberikan untuk mengukur pengetahuan dalam pengabdian masyarakat ini juga diukur sikap remaja dengan memberikan kuesioner pretest dan posttest. Hasil didapatkan bahwa sebagian besar remaja mempunyai sikap positif setelah diberikan penyuluhan tentang upaya Pendewasaan Usia Perkawinan, remaja menjawab dengan sikap positif sebesar 6 orang remaja $(85,8 \%)$, terjadi peningkatan sebelum dan sesudah diberikan penyuluhan. Namun masih ada remaja yang mempunyai niat untuk menikah dini sebanyak 1 orang remaja $(14,2 \%)$.

Sikap secara garis besar terdiri dari komponen kognitif (ide yang berkaitan dengan pembicaraan), perilaku (dapat cenderung mempengaruhi respon sesuai dan tidak sesuai), emosi (menimbulkan respon-respon yang konsisten) (Johariyah \& Mariati, 2018). Seseorang dapat bersikap positif atau negatif pada suatu objek dapat di bentuk melalui pengamatan pada perilaku diri sendiri. Sikap mempunyai hubungan tertentu terhadap suatu objek dengan kata lain sikap itu terbentuk, dipelajari atau berubah dengan suatu objek tertentu yang dapat dirumuskan dengan jelas dan tidak berdiri sendiri (Hartati et al., 2019).

Keberhasilan program Pendewasaan

Usia Perkawinan juga bergantung pada sikap remaja dalam mendewasaakan usia perkawinan. Menurut (Azwar, 2003) mengatakan bahwa beberapa faktor lain yang memberikan pengaruh kepada sikap remaja seperti adat atu kebiasaan yang ada dilingkungan sekitar, informasi dalam media masa juga berperan penting dalam pembentukan sikap terhadap objek tertentu.

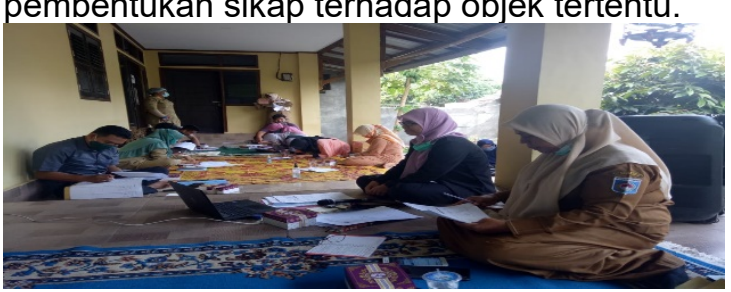

Gambar 2. Suasana Remaja Dalam Mengisi Kuesioner

Dalam kegiatan pengabdian masyarakat yang dilakukan (Gambar 2), meskipun kegiatan penyuluhan tentang upaya Pendewasaan Usia Perkawinan (PUP) dalam pengisian kuesioner di Lingkungan Tegal Sejahtera Kelurahan Selagalas Kecamatan Sandubaya terlaksana cukup baik, namun tidak terlepas dari beberapa permasalahan yang terjadi. Adapun beberapa permasalahan yang terjadi adalah masih ada remaja yang menjawab niat untuk menikah dini dan kurangnya media penyuluhan kesehatan yang ada di Lingkungan Tegal Sejahtera Kelurahan Selagalas Kecamatan Sandubaya (lembar balik, dan leaflet). Kurang media penyuluhan akan menghambat proses penyampaian informasi kepada sasaran. Sehingga solusi yang ditawarkan pada petugas PLKB adalah dengan memberikan materi powerpoint, lembar balik dan leaflet sehingga bisa digunakan oleh PLKB dalam kegiatan penyuluhan dalam upaya peningkatan pengetahuan remaja dalam Pendewasaan Usia Perkawinan.

Hasil penelitian menunjukkan adanya pengaruh pendidikan kesehatan reproduksi terhadap peningkatan pengetahuan dan sikap remaja (Panjaitan, Damayanti, Wiarisa, \& Lusrizanuri, 2017). Sehingga para remaja perlu diberi penyuluhan tentang materi dasat kependudukan, remaja dan program PUP sendiri. Sikap remaja setelah melalui kegiatan ini dapat dilihat dalam hasil posttest dimana rata-rata usia menikah yang diinginkan adalah $\geq 25$ tahun untuk remaja putri maupun putra. 
Hal ini sesuai dengan penelitian lainnya bahwa ada hubungan tingkat pengetahuan remaja dengan sikap tentang pernikahan usia dini (Lubis, 2012).

Kegiatan pengabdian masyarakat ini diharapkan dapat menekan angka pernikahan dini dengan meningkatkan atau mendewasakan usia pernikahan. Salah satu program pembangunan yang berkaitan dengan kependudukan adalah Program Keluarga Berencana yang bertujuan mengendalikan jumlah penduduk diantaranya melalui program Pendewasaan Usia Perkawinan (PUP). Pendewasaan Usia Perkawinan bertujuan untuk memberikan pengertian dan kesadaran kepada remaja agar di dalam merencanakan keluarga, mereka dapat mempertimbangkan berbagai aspek berkaitan dengan kehidupan berkeluarga, ditinjau dari aspek kesehatan, ekonomi, psikologi dan agama. Tujuan PUP seperti ini berimplikasi pada perlunya peningkatan usia perkawinan yang lebih dewasa sehingga berdampak pada penurunan Total Fertility Rate (TFR).

Pendewasaan Usia Perkawinan (PUP) adalah upaya untuk meningkatkan usia pada perkawinan pertama, sehingga pada saat perkawinan mencapai usia minimal 20 tahun bagi perempuan dan 25 tahun bagi laki-laki. Batasan usia ini dianggap sudah siap baik dipandang dari sisi kesehatan maupun perkembangan emosional untuk menghadapi kehidupan berkeluarga. PUP bukan sekedar menunda perkawinan sampai usia tertentu saja, akan tetapi juga mengusahakan agar kehamilan pertama terjadi pada usia yang cukup dewasa. Apabila seseorang gagal mendewasakan usia perkawinannya, maka diupayakan adanya penundaan kelahiran anak pertama.

Dalam kegiatan pengabdian lainnya para remaja dapat berperan meningkatkan pengetahuan dan skrening terkait kesehatannya melalui kegiatan posyandu remaja. Posyandu selain sebagai wadah untuk pemeriksaan kesehatan rutin bagi para remaja juga dapat dijadikan tempat konsultasi teman sebaya (Putri \& Rosida, 2017). Hal ini dapat dijadikan tambahan kegiatan di dalam struktur organisasi karang taruna sebagai wadah khusus untuk permasalahan kesehatan reproduksi bagi para anggotanya. Keunggulan luaran dari kegiatan pengabdian ini selain meningkatkan pengetahuan ada suatu bukti fisik sebagai komitmen bersama antara semua pihak yang terlibat dalam upaya pendewasaan usia perkawinan. Kelemahan dalam luaran ini adalah belum dapat diukurnya sampai perubahan perilaku pada remaja dimasa yang akan datang.

\section{SIMPULAN DAN SARAN}

Edukasi pendewasaan usia perkawinan di Lingkungan Tegal Sejahtera Kelurahan Selagalas Kecamatan Sandubaya, dalam kategori tingkat ketercapaian target luaran dalam kegiatan pengabdian masyarakat ini sudah sesuai dengan yang direncanakan. Metode yang digunakan adalah pemberian pendidikan kesehatan dirasa tepat sebagai solusi untuk menyelesaikan permasalahan mitra yaitu dalam bentuk penyuluhan kesehatan. Terjadi peningkatan pengetahuan remaja tentang upaya Pendewasaan Usia Perkawinan sebesar $85,8 \%$ dan sama terjadi peningkatan sikap positif pada remaja sebesar $85,8 \%$ dalam upaya Pendewasaan Usia Perkawinan.

\section{UCAPAN TERIMAKASIH}

Pengabdian masyarakat ini terlaksana atas partisipasi kerjasama PLKB Kota Mataram serta Remaja Karang Taruna di Lingkungan Tegal Sejahtera Kelurahan Selagalas Kecamatan Sandubaya Kota Mataram dalam kegiatan pengabdian masyarakat ini.

\section{DAFTAR RUJUKAN}

Ariany, D. M. (2019). Kasus Pernikahan Dini di Mataram Meningkat.

Ariany, D. M. (2020, September 15). DP3A Sesalkan Terjadinya Kasus Pernikahan Usia Anak. Suarantb.Com.

Azwar, S. (2003). Sikap Manusia Teori Skala dan Pengukurannya. Pustaka Pelajar, Jakarta.

BKKBN. (2010). Pendewasaan Usia Perkawinan dan Hak-hak Reproduksi bagi Remaja. Jakarta.

BKKBN, B. K. R. (2012). Pedoman Pengelolaan Pusat Informasi dan Konseling Remaja dan Mahasiswa (PIK Remaja/Mahasiswa). Jakarta: BKKBN.

Hartati, S., Verawati, M., \& Ernawati, H. (2019). Hubungan Pengetahuan Dengan Sikap Remaja Tentang Pendewasaan Usia Perkawinan. In 1st Prosiding Seminar Nasional Fakultas IImu Kesehatan (pp. 115-120).

Johariyah, A., \& Mariati, T. (2018). Efektivitas penyuluhan kesehatan reproduksi remaja dengan pemberian modul terhadap perubahan pengetahuan remaja. Jurnal Manajemen Kesehatan Yayasan RS. Dr. Soetomo, 4(1), 38-46.

Lubis, D. (2012). Tingkat Pengetahuan dan Sikap Remaja Putri tentang Kehamilan Usia Dini di Kota Denpasar. Archive of Community Health, 1(1), 63-68. 
Mubasyaroh, M. (2016). Analisis Faktor Penyebab Pernikahan Dini Dan Dampaknya Bagi Pelakunya. YUDISIA: Jurnal Pemikiran Hukum Dan Hukum Islam, 7(2), 385-411.

Notoatmodjo, S. (2010). IImu perilaku kesehatan. Jakarta: Rineka Cipta, 200, 26-35.

Panjaitan, A. A., Damayanti, R., Wiarisa, H., \& Lusrizanuri, K. (2017). Pengaruh Pendidikan Kesehatan Terhadap Peningkatan Pencegahan Pernikahan Dini. Wawasan Kesehatan: Jurnal IImiah Ilmu Kesehatan, 3(2).

Putri, I. M., \& Rosida, L. (2017). Pelatihan Kader Pembentukan Posyandu Remaja Di Dusun Ngentak Bangunjiwo Kasihan Bantul Yogyakarta. In Prosiding Seminar Nasional dan Internasional (Vol. 1).

Putri, I. M., \& Rosida, L. (2019). Peningkatan Pengetahuan Program Pendewasaan Usia Perkawinan di Karang Taruna Angkatan Muda Salakan Bantul Yogyakarta. Jurnal Pengabdian Masyarakat Kebidanan, 1(1), 5-11. 